\title{
Kalitatearen kudeaketa adineko pertsonen egoitzetan eta UNE 158001 estandarraren eguneraketa: zaharra berri?
}

\author{
Erlantz Allur \\ Ekonomia eta Enpresa Fakultatea (Gipuzkoako Atala) \\ Euskal Herriko Unibertsitatea (UPV/EHU) \\ erlantz.allur@ehu.eus
}

\section{Ander Ibarloza \\ Ekonomia eta Enpresa Fakultatea (Egoitza) \\ Euskal Herriko Unibertsitatea (UPV/EHU)}

\author{
Alberto Díaz de Junguitu \\ Ekonomia eta Enpresa Fakultatea (Gipuzkoako Atala) \\ Euskal Herriko Unibertsitatea (UPV/EHU)
}

\begin{abstract}
2006. urtean autonomia pertsonala sustatzeari eta mendekotasun egoeran dauden pertsonak zaintzeari buruzko Espainiako Legea sartzearekin batera, AENOR-eko normalizaziorako AEN/CTN 158 batzorde teknikoak UNE 158001 estandarraren bertsio berria garatu zuen 2015. urtean. ISO 9001 estandar arrakastatsuak sektorean izan zuen hedapenak eragin handia izan zuen hedapen horretan. UNE 158001 estandar multzoak zerbitzu prestazioan jartzen du arreta gehien, eta adineko pertsonen egoitza, eguneko eta gaueko zentro, etxez etxeko laguntza zerbitzuaren eta telelaguntza zerbitzuaren kudeaketari dagozkion aspektuak eta zenbait betekizun jasotzen ditu. Artikulu honen helburua UNE 158001:2015 estandarraren azken eguneratzeak dakartzan aldaketa nabarmenenak berrikusi, eta dagoeneko estandar honekin lanean diharduten zentroetan zer nolako eragina izan duen eta izan dezakeen aztertzea da. Horretarako, metodologia kualitatiboan oinarritutako landa lan labur bat egin da sektoreko profesionalekin egindako zenbait elkarrizketatan oinarrituta. Azken batean, ikerlan garatuago baten aurrekaria da artikulu hau, eta bere xedea da aribidean dagoen ikerlan bateko datuak aurkeztea.
\end{abstract}

\section{GAKO-HITZAK:}

Kalitatearen kudeaketa, kudeaketarako estandarrak, UNE 158001, adineko pertsonen egoitzak.
Con la entrada en vigor de la Ley de Promoción de la Autonomía Personal y Atención a Personas en Situación de Dependencia, el Comité Técnico de Normalización AEN/CTN 158 de AENOR presentó en 2015 la nueva versión de la norma UNE 158001. La extensa aceptación de la ISO 9001 dentro del sector propició una mayor difusión de la UNE 158001. El estándar está enfocado a la prestación de servicios, y en este sentido, recoge cuestiones que se han de considerar en la gestión de residencias para personas mayores, centros de día y de noche, servicios de atención domiciliaria y el servicio de teleasistencia. Este artículo, elaborado a partir de entrevistas con los/as profesionales del sector, pretende analizar las novedades más relevantes de la UNE 158001:2015 y revisar su repercusión en los centros que trabajan con ella. Se trata, en definitiva, de presentar los primeros resultados de una investigación en curso.

\section{Palabas Clave:}

Gestión de la calidad, estándares de gestión, UNE 158001, residencias para personas mayores. 


\section{Sarrera}

Merkatuen etengabeko integrazioa eta globalizazio prozesua bereizgarritzat dituen ingurune ekonomiko batean, enpresa kudeaketarekin erlazionatutako normalizazio prozesua bizkortu egin da. Normalizazioa, industria, teknologia, zientzia eta ekonomiaren alorrean izaten diren erabilera errepikakorrak taxutzea helburu duen jarduera da (Heras, 2004). Gaur egun, normalizazioak, kalitatea hobetzeko enpresen ekintza operatiboak taxutu eta sistematizatzen ditu (baita, besteak beste, ingurumenarekin zerikusia duten jarduerak eta lan arriskuen prebentzioari buruzkoak ere).

Ohiko erregulazio erakundeetatik haratago, administrazio publikoarekin inolako erlaziorik ez duten erakunde erregulatzaileak sortzen joan dira azken urteotan. Horien artean aipagarria da, esaterako, Estandarizaziorako Nazioarteko Erakundea, ISO akronimoaz ezagunagoa dena (International Organization for Standarization), eta nazioarteko normalizaziorako erakunde garrantzitsuen bezala diharduena 1947 az geroztik. Gisa berean, herrialde bakoitzak arau ofizialak egitearen ardura duen normalizaziorako erakundea izaten du; Espainian AENOR izenekoak (Asociación Española de Normalización y Certificación) garatutako arauek UNE izena hartzen dute.

Testuinguru honetan, kudeaketarako sistema eta ereduen ezarpenak esparru soziosanitarioan ere hedapen zabala izan du. Hau oraindik eta argiagoa da gizarte zerbitzuena bezalako sektore batean, eta bereziki adineko pertsonen egoitzen inguruan, orain gutxi arte kudeaketa gehiegi profesionalizatu gabe egon den eremu batean, hain zuzen ere (Heras, 2008).

Hala, adineko pertsonen egoitzek aldaketa ugari izan dituzte: gizartearengandik nahiko urrun egotetik, gizartean gero eta esangura nabarmenagoa duten testuinguru batera igaro dira. Gainera kudeaketa gero eta eraginkorragoa eskatzen dute, bai administrazio publikoek eta baita gizarteak berak ere, egoiliarrei ahalik eta arretarik hoberena eskaini eta zentroek baliabide publikoei erabilera aproposena eman dakien.

Honen haritik, adineko pertsonen arretari dagokion esparruan duela urte gutxi ez bezalako kudeaketa kultura barneratzen ari da. Aldaketa hau denbora oso gutxian eman da -beste sektore batzuetan baino modu azkarragoan bai behintzat - eta orain arte industria esparruan baino erabiltzen ez ziren kudeaketarako tresnak barneratzea eta erabiltzen hastea ekarri du.

Era berean, autonomia pertsonala sustatzeari eta mendekotasun egoeran dauden pertsonak zaintzeari buruzko Legean kalitatea kontzeptu gisara barneratu izanak bere aplikagarritasun praktikoaz gero eta interes handiagoa izatea ekarri du, eta era berean gainontzeko legedi berriek kalitatearen kontzeptua erreferentziatzat hartzea sustatu du (Medina eta
Ruiz, 2011). Baina kalitatearen paradigmak sektore soziosanitarioan dituen berezitasunak asko dira industria sektorean dituenarekin alderatuz gero. Besteak beste, sektore soziosanitarioan lan egiten duten profesionalek duten erantzukizuna (Sacanell, 1994), edo egoitzei dagokien kalitate kontzeptua bera aipa daitezke - oro har onartuak izan diren bestelako definizioetatik haratago eramaten gaituztenak, bide batez esanda-. Zentzu honetan "bezeroa" eta "asebetetzea” bezalako oinarrizko kontzeptuak eztabaidagai izan daitezke. Nori gagozkio bezeroa diogunean? Agian egoitza zerbitzua eskatzen duen pertsona edo erakundeari? Hausnarketa sakona eskatzen duten galderak dira, zalantzarik gabe.

Estatu mailako ordenamendu juridikoak, adineko pertsonen zentroetako kalitate inspekzioak eta akreditazioa burutzeko lana autonomia bakoitzeko administrazio publikoen esku uzten du, eta agian horrek ekarri du halako garapen heterogeneoak garatu izana autonomia erkidego batetik bestera. Horiek horrela, eta aipatutako gogoetak alde batera utzita, sektore soziosanitarioan hedapen zabalena izan duten kalitate ereduak ISO 9001 estandarra edota EFQM autoebaluazio ereduan oinarritu dira batez ere - hein batean, adineko pertsonen egoitzetan eskaintzen den zerbitzu espezifikoetara egokituz-, eta sektoreko beste kalitate eredu espezializatuak alde batera utzita.

Badirudi sektore honetan ISO 9001-en ezarpenak izan duen hedapen zabala - hein handi bateanadministrazio publikoek kudeaketa eredu konkretu hauek erabiltzeko egindako sustapenarekin oso lotuak daudela. Bestelako eragile eta preskribatzaileekin batera (elkarte, erakunde zertifikatzaile edo aholkularitza enpresak) aurrera eramandako elkarlanak dagoeneko 10 urtetik gorako ibilbidea duen honetan, interesgarria izan daiteke sustapen politika horiek izandako benetako ondorioen inguruan hausnartzea. Eta gogoeta hau oraindik eta beharrezkoagoa izan daiteke, krisialdi ekonomikoak eraginda, sektore soziosanitarioko inbertsio eta gastu partidetan doitze neurri zorrotzak aplikatzen ari diren honetan.

ISO 9001 bezalako estandar generikoak adineko pertsonen egoitzetan barneratzeak onura nabarmenak ekarri ditzakeela berresten dute zenbait ikerketek. Zehazki esanda, ekarpen horiek diote kudeaketa sistematizatzeko eta lan metodologiak barneratzeko balio dezakeela, eta bereziki prozesu administratiboetan egin ditzakeela ekarpenik garrantzitsuenak - adineko pertsonen egoitzetako egoiliarrei eskainitako arretaren kalitatean hain argi geratzen ez diren ondorioak dira hauek, ordea-. Eta abantaila potentzial horiek, estandarra bera ezartzeko moduarekin oso lotuak egoten dira, izan ere, berau ezartzen duten antolaketetako pertsonek eredua berreraiki egiten dute antolaketa horretara eta jarduera konkretuetara egokituz. Horregatik, adineko pertsonen egoitzen kasuan zuzeneko arreta eskaintzen duten profesionalek ezarpen prozesu honetan partehartzea ezinbestekoa litzateke. 
Aitzitik, badira adineko pertsonen egoitzen esparruan interes eta aipamen berezia merezi duten kalitate eredu espezifikoak ere. Horien artean aurki daitezke: SERA eredua (adineko pertsonen egoitzak ebaluatzeko sistema) eta Eguía-Careaga Fundazioak eta SIIS Dokumentazio eta Ikerketa Zentroak garatutako kalitatearen bermerako SIIS-Kalitatea Zainduz eredua; lehenengoa MEAP (Multiphasic Environmental Assesment Procedure) delakoan oinarritzen da, eta egoiliarren ezaugarri fisiko, soziodemografiko, psikosozial eta pertsonalak hartzen ditu kontuan; eta bigarrenak, berriz, HAFLI eredua du oinarria (SIIS Dokumentazio eta Ikerketa Zentroa, 2001). Bada, bestalde, adineko pertsonen egoitzetan kalitatea sustatzeko 100 gomendio jasotzen dituen beste lan bat ere, Espainiako Geriatria eta Gerontologia Elkarteak argitara emandakoa. Eta era berean, artikulu honetan hizpide izango dugun UNE 158001:2015 estandar espezifikoak aipamen berezia merezi du.

\section{UNE 158001 estandarra}

UNE 158001 adineko pertsonen egoitzen kudeaketarako estandar espezifikoa da, 2000. urtean AENOR-ek sortua. Bertan jasotzen denez, estandar honek "adineko pertsonen egoitzetan burutzen den jardueraren erreferentzia izan nahi du, eta eskainitako zerbitzuaren, bezeroekiko harremanen eta zerbitzu emaile diren profesionalen arteko harremanak erraztea du helburu" (AENOR, 2010). Adineko pertsonen egoitzek bezeroaren beharrak asetzeko bete beharreko gutxieneko baldintza eta zerbitzuak zehazten ditu, eta egoitzaren kudeaketa orokorra, zerbitzu prestazioa eta kalitate sistema baten ezarpenarekin erlazionatutako kudeaketa jasotzen ditu.

Estandar honek arreta gehien eskaintzen dion atala zerbitzu prestazioarena da. Aurreikusitako zerbitzu bakoitzarentzat zenbait betekizun zehazten ditu: zerbitzuaren beraren definizioa, beharrezko giza baliabide eta bitarteko materialen zerrendaketa eta langileek eduki beharreko formazio espezifikoaren deskribapena, besteak beste. Horrez gain, estandarrak beste betekizun gehiago ere zehazten ditu: arreta eta zaintzarako plan espezifikoak izatearena, adibidez. Bezeroa “egoitza bateko zerbitzua jasotzea eskatu duen pertsona edo erakunde" bezala definitzen du, eta bere gogobetetzea ebaluatzea ere beste betekizunetako bat da. Hala, bezero horien gogobetetze maila neurtzeko programa bat zehaztera derrigortzen du egoitza.

Euskal Autonomia Erkidegoan (EAE) egindako ikerketa enpiriko ezberdinek erakutsi dute oraindik ez direla UNE 158001 estandarraren helburu eta jardute eremua behar bezala ezagutzen (Iradi, 2006). Adituek, gure ekarpen labur honetarako egindako landa lanean ere egiaztatu denez, estandar honek adineko pertsonen egoitzen testuinguruan baliagarriak direla iritzi badiote ere, zenbait muga aipatzen dituzte zentro hauetako bakoitzaren arreta eredu propioak ez baitira sarri askotan barneratzen. Gainera, zenbait egoeratan -EAE-ko kasuan, esaterako- estandarrak finkatutako betekizunak ez dira indarrean dauden legediak zehaztutakoak bezain zorrotzak izaten. Egoitza horien kudeatzaileek egiten dituzten gogoeta kritikoen artean aipagarria da, bestalde, Administrazio Publikoak berak edo hirugarrenek egindako ikuskaritzek batez ere estandar fisikoetan eragiten dutela, eta ez dituztela egoiliarren bizi kalitatearekin erlazionatutako oinarrizko aspektuak kontuan hartzen. Aitzitik, AENOR-ek (2016) hurrengo taulan aurkezten diren UNE 158001 estandarraren ezarpenarekin lotutako honako abantailak deskribatzen ditu.

1. taula. UNE 158001 estandarraren onurak

\begin{tabular}{|c|c|}
\hline Antolaketentzat onurak & Bezeroentzat onurak \\
\hline $\begin{array}{l}\text { - Zerbitzu prestazio } \\
\text { konkretuarekin lotutako } \\
\text { legedia betetzea errazten } \\
\text { die adineko pertsonen } \\
\text { egoitza eta eguneko } \\
\text { zentroei. } \\
\text { - Zerbitzuak modu } \\
\text { eraginkor, seguru eta } \\
\text { profesionalago batean } \\
\text { kudeatzen laguntzen du, } \\
\text { eskainitako zerbitzuaren } \\
\text { etengabeko ebaluaketa eta } \\
\text { jarraipenerako zehaztutako } \\
\text { kudeaketa adierazleei } \\
\text { esker. } \\
\text { Merkatuko beste zerbitzu } \\
\text { prestatzaileengandik } \\
\text { desberdintzapen } \\
\text { handiagoa dakar. }\end{array}$ & $\begin{array}{l}\text { - Erabiltzaileen asebetetzea } \\
\text { lortzeko oinarri bezala finkatzen } \\
\text { dira arreta profesionalizatua, } \\
\text { babes psikosoziala eta } \\
\text { familiarra, elkarbizitza eta } \\
\text { ingurunearekiko harremana } \\
\text { bera ere. } \\
\text { - Estandarrean jasotako } \\
\text { betekizunek erabiltzaile eta } \\
\text { zerbitzu prestatzaileaz gain, } \\
\text { gainerako interes talde gehiago } \\
\text { ere kontuan hartzen ditu, } \\
\text { senitartekoak edo osasun } \\
\text { zerbitzuekin aurrera eramango } \\
\text { diren interakzioak, esaterako. } \\
\text { - Ziurtapenari esker, bezeroek } \\
\text { zentroen inguruko informazio } \\
\text { publiko eta gardena jaso } \\
\text { dezakete, eta zerbitzu } \\
\text { prestatzaile ezberdinak } \\
\text { identifikatzen eta ezberdintzen } \\
\text { lagun dakieke. }\end{array}$ \\
\hline
\end{tabular}

Iturria: AENOR (2016)

UNE 158001 estandarraren araberako ziurtagiri hauek, ISO 9001 estandarrarekin bateragarriak eta osagarriak dira aldi berean. Kudeaketa sistema baten ohiko tresnak kontuan hartzeaz gain, zerbitzuaren kalitateari dagozkion betekizunen inguruko definizioekin osatzen dira. Bi ziurtagirien arteko integrazioari esker ziurtapen prozesua bera optimizatu eta ikuskaritza denbora eta kostuak murrizten dira, eta aldi berean egindako ezarpenak hainbat betekizun partekatzea dakarrenez, informazio guztia dokumentazio multzo bakarrean bateratzea ere ekartzen du.

Aldiz, Heras-Saizarbitoria eta Boiral-ek aipatzen dutenez (2013) estandar hauen ezarpena argudiatzen duten arrazoiak aztertzerakoan ikuspegi orokorrago eta teorikoago batetik jo beharko litzateke. Egile horien arabera, aipatu estandarrak ezartzen dituzten antolaketek nolabaiteko zilegitasuna lortzen dute, eta honek bestelako abantailak ere ekartzen dizkiete (Beck eta Walgenbach, 2005). Gauza bera ondorioztatzen dute, gisa berean, bestelako ikuspegi tekniko ezberdinek ere (Nair eta Prajogo, 2009). Gai hau ez da arrotza, batez ere Boiral eta Gendron (2011) edo Power (2003) bezalako egileen 
arabera hirugarrenek egindako ziurtatze horiek konfiantza sortzera eta zilegitasun soziala sustatzera bideratutako bitarteko bezala ulertzen baitira.

Kalitatea "bezeroaren gogobetetzea" bezala jasotzen duen ohiko definizioaz gain, hizpide dugun sektore soziosanitarioko kasuan, bada kontzeptu honen beste dimentsio bat ere "kalitate tekniko" edo "kalitate asistentziala" bezala ezagutzen dena (Villegas eta Rosa, 2003). Adibidez, Sacanell-ek (1994) dion bezala, egoera batzuetan egoiliarren beharrizanak ezin daitezke asetu, euren kalterako ondorioak izan ditzaketelako eskaera horiek. Era berean, egoiliar bat asebete gabe gera daiteke profesional gaituek eskainitako zerbitzuaren aurrean, eta aitzitik, gogobeteta hain gaituak ez direnek emandakoekin (Kahn, 1980). Laburbilduz, kontuan eduki beharreko aspektua da egoera batzuetan kalitate asistentzialaren neurketa sektoreko profesional eta teknikariek egin behar dutela, eta hemendik dator, bada, "kalitate teknikoaren" kontzeptua. Aldiz, Medinak (1996) dion modura, beste kasu askotan, jasotako arretaren inguruko kalitateaz eztabaidatzeko irizpidea eta ezagutza nahikoa izan dezakete egoiliarrek.

\section{UNE 158001 estandarraren eguneraketa}

UNE 158101, UNE 158201, 158301 eta 158401 estandarrak adineko pertsonen egoitza, eguneko zentro, etxez etxeko laguntza zerbitzuan eta telelaguntza zerbitzuan gero eta ohikoagoak diren egoera berriei aurre egiteko eguneratuak izan dira. 2006. urteaz geroztik sektoreak aldaketa sakonak izan ditu, eta horrenbestez egungo egoerara gehiago hurbilduko den estandarra berrikustea ezinbestekoa izan da.

2015. urtean aurkeztu zen estandar berri honek zerbitzu prestazioan jartzen du arreta gehien. Hala, identifikatutako zerbitzu jakin bakoitzarentzat zenbait betekizun zehazten ditu: zerbitzuaren definizioa, giza baliabide eta baliabide materialen zerrendaketa, eta zerbitzua eskainiko duten profesionalek izan beharreko formazio mailaren inguruko aipamena, kasu. Era berean, estandarrak arreta eta zaintza plan zehatza edukitzeko premia azpimarratzen du. Bestalde, bezeroaren gogobetetzeari dagokion ebaluaketa ere kontuan hartu beharreko beste betekizunetako bat da; hau neurtu eta ebaluatzeko programa jakin bat finkatua edukitzeko obligazioarekin.

Adineko pertsonen egoitzei dagokien kalitate kudeaketaren inguruko atalean, estandarrak zentro horien Kalitate Kudeaketarako Sistemek (KKS) izan beharreko egitura zehazten du "eskainitako zerbitzu guztietan modu sistematikoan aplikatuko diren lan ildo multzo bezala" definituz (AENOR, 2000). Finean bestelako sistemen normalizazio esparruan ohikoak diren egitura eta betekizunak jasotzen dituen Sistema baino ez da, adineko pertsonen egoitzen testuingurura egokitua. Kalitatearen esparruko egitura zehazteaz gain, kalitate politika definitu eta dokumentatzeko, neurgarriak diren kalitate helburuak zehaztu, eskainitako zerbitzuetarako hobekuntza neurriak proposatu, eta lantaldearen egitekoak eta erantzukizunak dokumentatzeko beharra zehazten du.

\subsection{UNE 158101: adineko pertsonen egoitzak}

UNE 158101 estandarrak adineko pertsonen egoitzei eta eguneko edo gaueko zentroa duten egoitzei dagozkien egiaztatze sistemak eta irizpideak finkatzen ditu. 2014. urtean AEN/CTN 158/SC 1 batzorde teknikoa estandarraren edukiak eguneratzeko lanean hasi zen, sektore honetako antolaketa horiek izaten dituzten beharretara hobekiago egokitzeko. la urte eta erdiz egindako lanaren ostean, erabilitako terminologia sinplifikatu eta estandarraren interpretazioa ere erraztu egin da. Emaitza gisara UNE 158101:2015 estandarra aurkeztu da. Berritasun garrantzitsuenen artean aipagarria da helburu berri bat barneratu izana: "pertsonen zuzendaritzari dagokien jardunbide egokiak sustatzea, eta profesionalek zerbitzuaren hobekuntzan partehartzea”. Helburu honekin lotuta, atal berri bat ere sortu da "pertsonen zuzendaritza politika" deritzona. Bestalde, estandarraren atal eta azpiatal desberdinen berregituraketa burutu da, 7 atal izatetik 11 atalera pasatuz. Aipagarria da, zentzu honetan, "kalitate adierazleak" atala gehitu izana; adierazleak prozesuka sailkatzen ditu taula bakarrean, eta hauen kalkulurako eta eguneraketarako gutxieneko maiztasuna zehazten da. Horrez gain, erabiltzaileen arretarako zerbitzuari garrantzi handiagoa eskaini zaio, eta jarraipen baloraketak txertatzeko atal berria ere sortu da baloraketak burutu ahal izateko epe maximoak zehaztuz. Bide bertsutik, eguneroko jardueran benetan erabilgarriak diren adierazleen berrikuspena ere egin da (30 izatetik 24ra pasatuz).

2. taula. UNE 158101 estandarraren edukia

\begin{tabular}{|l|}
\hline o. Sarrera \\
\hline 1. Aplikazio esparrua \\
\hline 2. Definizio eta terminoak \\
\hline 3. Printzipio eta helburuak \\
\hline 3.1. Printzipioak \\
3.2. Helburuak \\
\hline 4. Pertsona erabiltzaileak zerbitzu prestazioan barneratzea \\
\hline 4.1. Zerbitzu prestazioa \\
\hline 5. Pertsona erabiltzaileei eskainitako arreta \\
\hline 5.1. Bezeroekin erlazionatutako prozesuak \\
5.2. Jarraipen baloraketak \\
5.3. Bakarkako Arreta Plana \\
5.4. Arreta eta zaintza pertsonalak \\
5.5. Osasun arreta \\
5.6. Arreta psikosoziala \\
\hline 6. Zerbitzuan baja ematea \\
\hline 6.1. Zerbitzuaren amaiera \\
6.2. Gutxieneko erregistroak \\
\hline 7. Pertsonen zuzendaritza \\
\hline 7.1. Pertsonen zuzendaritzarako politika \\
7.2. Zuzendaritzaren erantzunkizuna \\
\hline
\end{tabular}




\begin{tabular}{|l|}
\hline 8. Antolaketa eta funtzionamendu aspektuak \\
\hline 8.1. Zerbitzu prestazioaren planifikazioa \\
8.2. Zentroaren kudeaketa sistema \\
8.3. Kudeaketa plana \\
\hline 9. Laguntza eta azpiegitura zerbitzu orokorrak \\
\hline 9.1. Azpiegiturak eta ekipamendua \\
9.2. Erosketa prozesua \\
9.3. Ostalaritza arreta \\
\hline 10. Jarraipena eta hobekuntza \\
\hline 10.1. Bezeroen asebetetze mailaren neurketa \\
10.2. Zentroaren kudeaketa sistemaren ziurtapena \\
\hline 11. Kalitate adierazleak \\
\hline A eranskina: zentroen helburu espezifikoak \\
\hline B eranskina: egoiliarren eskubide eta betebeharrak \\
\hline
\end{tabular}

Iturria: AENOR (2016).

Adineko pertsonen egoitzak kudeatzeko gutxieneko betekizunak zehazten dituen estandar bat izatean, zerbitzua kalitate irizpideekin eta sektore profesionalizatu batekin eskainiko dela bermatzen da. Honen haritik, etengabeko ebaluaketa eta jarraipena oinarri izango dituen kudeaketa eraginkorragoa ere gaitzen da. Sektoreko emaitzak alderatzerakoan, horrez gain, beren kalkulurako bateratutako irizpideak dituzten adierazleak definitu izana ere lagungarri gerta daiteke. Azpimarragarria da, era berean, UNE 158101 estandarrak zentroko pertsona erabiltzaileez gain, inguruneko beste eragileak ere -familia edo gizartea, esaterakokontuan hartzen dituela.

\subsection{UNE 158201: eguneko zentroak}

Eguneko zentroak gizarte zerbitzuen sarean erabat integratuak dauden funtsezko baliabide bihurtu dira. Mendekotasun egoeran dauden pertsonei oinarrizko beharrak, eta behar terapeutiko edo sozialak asetzen dizkiete, hau guztia pertsona hauetako bakoitzaren autonomia eta bizi kalitatea areagotzeko bitartekoak jarriz. Zerbitzu honek, gainera, pertsona erabiltzailea ahalik eta epe luzeenean bere ohiko ingurunean bizitzea laguntzen du. Aurreko guztiagatik, zentro horietan arreta eredu egokia diseinatu eta, horren arabera, lanerako jardunbideak finkatzea benetan beharrezkoa da.

Bide honetatik, UNE 158201 estandarrak eguneko zentroek eskainitako zerbitzuaren kalitatea bermatzeko betekizunak zehazten ditu, aurreko bertsioan jasotako irizpideak aintzat hartuta. Estandar honen erabilerak berak eta eguneko zentroen arreta ereduetan izandako aurrerapenei esker, AEN/CTN 158/SC2 batzorde teknikoak aldaketa ugari sartu ditu aipatu estandarrean. Zehazki esanda, eguneko zentroen egunerokoan gero eta ohikoagoak diren termino berriak barneratu dira. Bestetik UNE 158001 estandarrean jasotako terminologiarekiko hurbilagoko definizio berriak ere txertatu dira. "Aukera berdintasuna" eta "erabiltzaileen askatasuna bermatzea”, zaintza eta arreta lanerako oinarrizko bi printzipio gisara ezarri dira. Horrez gain, eguneko zentroek erabiltzaile diren pertsona, senitarteko, zaintzaile eta gainerako interes taldeei dagozkien helburu espezifikoak ere zabaldu egin dira. Estandar berriak balorazio integralean aspektu sozio-familiarra barneratzen du, eta prozesuan zehar jasotako beste balorazio espezializatuak ere gehitzeko aukera eskaintzen du.

Zuzendaritzak eta zenbait diziplina anitzeko taldeen koordinazioak eguneko zentroen funtzionamenduan duten garrantzia dela eta, giza baliabideen zuzendaritza zena pertsonen koordinazio eta zuzendaritza izatera pasatu da. Eskainitako zerbitzuaren ebaluazioari dagokionez ondorengo 8 prozesu hauek zehaztu dira: zerbitzuaren hasiera; bakarkako arreta plana; eskuartze programak; zentroaren zerbitzuak; zerbitzuaren kalitatearen barne ebaluazioa; giza baliabideak; formazioa; eta zerbitzuaren amaiera. Aurreko horien jarraipenerako

3. taula. UNE 158201 estandarraren adierazleak

\begin{tabular}{|c|c|c|}
\hline Prozesuak & Adierazleak & Maiztasuna \\
\hline $\begin{array}{l}\text { Zerbitzuaren hasiera eguneko eta } \\
\text { gaueko zentroetan }\end{array}$ & Hasierako baloraketa egina duten pertsona erabiltzaileen portzentaia & Hiruhilekoa \\
\hline \multirow[b]{2}{*}{ Bakarkako Arreta Plana (BAP) } & Hasierako BAP-a egina duten pertsona erabiltzaileen portzentaia & Hiruhilekoa \\
\hline & $\begin{array}{l}\text { BAP-a sei hilean behin eguneratu zaien pertsona erabiltzaileen } \\
\text { kopurua }\end{array}$ & Seihilekoa \\
\hline \multirow{4}{*}{ Eskuartze programak } & Erorketak izan dituzten pertsonen portzentaia & \multirow{4}{*}{ Hilerokoa } \\
\hline & Kontrolatu gabeko irteerak izan dituzten pertsonen portzentaia & \\
\hline & $\begin{array}{l}\text { Gizarte eta kultura jardueratan parte hartzen duten pertsonen } \\
\text { portzentaia }\end{array}$ & \\
\hline & $\begin{array}{l}\text { Senitartekoei zuzendutako jardueratan parte hartzen duten familia } \\
\text { portzentaia }\end{array}$ & \\
\hline \multirow{2}{*}{ Zentroaren zerbitzuak } & Sendagaiak administratzerakoan izandako gertakari portzentaia & \multirow{2}{*}{ Hilerokoa } \\
\hline & Lotura mekanikoak dituzten pertsona erabiltzaileen kopurua & \\
\hline Zerbitzu amaiera & Egokitu ez izanagatik zerbitzuan izandako bajak & Hiruhilekoa \\
\hline \multirow{3}{*}{$\begin{array}{l}\text { Zerbitzuaren kalitatearen barne } \\
\text { ebaluaketarako prozesua }\end{array}$} & Asebeteak dauden pertsona erabiltzaileen portzentaia & \multirow{2}{*}{ Urterokoa } \\
\hline & Asebeteak dauden senitartekoen portzentaia & \\
\hline & Kexak jarri dituzten erabiltzaile eta familiartekoen portzentaia & Hilerokoa \\
\hline Giza baliabideak & Asebetea dagoen langile portzentaia & Urterokoa \\
\hline Formazioa & Formazioa jaso duen langile portzentaia & Urterokoa \\
\hline
\end{tabular}

Iturria: AENOR (2016). 
lagungarri izango diren adierazle koadroak ere ezarri dira, bestalde. Estandarrak, era berean, bi eranskin ditu: lehenengoa erabiltzaileen eta legezko ordezkarien eskubide, obligazio eta erantzukizunak jasotzen dituena, eta bigarrena eguneko edo gaueko zentroen instalakuntzen inguruko informazioa eskaintzen duena.

Finean eguneko zentroek eskainitako zerbitzuaren kalitatearen kudeaketa eta etengabeko hobekuntza lortzeko tresna bezala har daiteke estandar hau. Bere aplikazioak antolaketa batean ezinbesteko diren motibazioa eta taldean lan egiten jakitea bezalako onurak ekar ditzake. Barne komunikazioak ere hobera egin dezake, eta know-how-aren transferentzia sendotu liteke. Labur esanda, merkatu aukera aldakorren aurrean erantzuteko gaitasun handiagoa eta malguagoa izan dezakete sektore honetako zentroek.

Zentzu honetan, UNE 158201 estandarra pertsona erabiltzaileak eta bestelako interes taldeak kontuan hartuz aplikatzen bada, antolaketarekiko duten konfiantzan eta leialtasunean erabateko eragina izango du honek, azken batean, pertsona horiei eskaintzen zaien zerbitzuak asetzen dituela eta euren ongizaterako lanean dihardutela erakusten baitu.

\subsection{UNE 158301: etxez etxeko zerbitzua}

AEN/CTN 158/SC3 batzorde teknikoak UNE 158301 estandarrean egindako eguneraketen diseinuan sektoreko 20 erakunde baino gehiagok parte hartu dute. Hala, eguneraketa burutzerakoan zerbitzu honen ohiko lengoaia mantentzeko ahalegina egin $\mathrm{da}$, eta erabateko praktikotasuna eman nahi izan zaio berezkoak dituen aspektu guztiak barneratuz: zerbitzuaren diseinua, zerbitzu prestazioaren hasiera, arreta eskaintzea, jarraipena eta zerbitzu prestazioaren amaiera.

Aldaketa guztien artean bi dira aipagarrienak: bata pertsonen zuzendaritzari, eta bestea kalitate adierazleei dagokiona. Lehenengoak kudeaketa arloan honako aspektuak barneratzea proposatzen du: arreta printzipio eta baloreekin lotutako zerbitzuaren ikuspegi orokorra; zerbitzuaren helburu, ezaugarri, emaitza, lorpen eta erronken komunikazioa eta partekatzea; lankidetza eta errespetuzko giroa sortzea; profesionalak etengabeko hobekuntzan barneratzea eta euren lanari aitortza egitea; eta pertsonen zuzendaritzarako eredu berriak barneratzea, besteak beste. Eta bigarrenik, estandarrean jasotako beste hobekuntza garrantzitsua dugu bestalde, zerbitzuaren kalitate adierazleak definitu izana. Erabiltzaile diren pertsonekin eta euren asebetetzearekin erlazionatutako adierazleek honakoak jasotzen dituzte, esaterako: urteroko jarraipen bisitak, zerbitzuarekin gogobeteta ez dagoen kasuan prestazioa bertan behera uztea, epe barruan erantzundako erreklamazio eta kexak, zoriontze ratioak, epe barruan kudeatutako alta berrien kopurua, eta zerbitzuarekin asebetea dagoen pertsona erabiltzaile kopurua. Langileei dagokionez, adierazleek kontuan hartzen dituzte, bestalde: langile bakoitzak jasotako formazio ordu kopurua, pertsona erabiltzaileek izaten dituzten laguntzaile aldaketak, eta azken horien errotazioa.

4. taula. UNE 158301 estandarraren edukia

\begin{tabular}{|l|}
\hline 1. Definizioa eta hasiera \\
\hline $\begin{array}{l}\text { 1.1. Zerbitzuaren helburuak } \\
\text { Pertsona erabiltzaileekin } \\
\text { - Pertsonen zuzendaritza }\end{array}$ \\
\hline 1.2. Pertsona erabiltzaileen eskubideak \\
\hline $\begin{array}{l}\text { 1.3. Giza baliabideak } \\
\text { - Konpromisoak } \\
\text { - Formazioa } \\
\text { - Lantalde profesionalak }\end{array}$ \\
\hline 1.4. Bitarteko tekniko eta materialak \\
\hline $\begin{array}{l}\text { 1.5. Zerbitzuaren hasiera } \\
\text { • Aurretiazko informazioa } \\
\text { - Zerbitzuan alta ematea }\end{array}$ \\
\hline 1.6. Baloraketa \\
\hline 2. Arreta \\
\hline $\begin{array}{l}\text { 2.1. Pertsona erabiltzaileei arreta } \\
\text { • Arreta pertsonala } \\
\text { • Etxebizitzako beharrizanei erantzuna ematea } \\
\text { dabes psikosoziala, familiarra eta inguruneko harremanei }\end{array}$ \\
\hline 2.2. Protokolo eta erregistroak \\
\hline 2.3. Zerbitzu osagarriak \\
\hline 3. Koordinazio eta jarraipena \\
\hline 3.1. Koordinazioa \\
\hline 3.2. Jarraipenerako bisita \\
\hline 3.3. Jarraipena, hobekuntza eta kalitate adierazleak \\
\hline 3.4. Zerbitzu prestazioaren amaiera \\
\hline
\end{tabular}

Iturria: AENOR (2016).

\section{Jasotako behin-behineko zenbait emaitza eta zenbait ondorio}

Aurreko ataletan aurkeztutako hausnarketak osatzeko, eta batez ere, UNE 158001 estandarrak 2015. urtean izandako eguneraketak zer-nolako harrera izan duen aztertzeko, Euskal Autonomia Erkidegoko (EAE) hiru adineko pertsonen egoitzen kasuak aztertu ditugu. Hiru zentroek UNE 158001 eta ISO 9001 estandarrarekin lan egiten dute, eta gutxienez 5-10 urteko ibilbidea dute hiruek ere. Zentzu honetan, zentroetako zuzendari eta kalitate saileko arduradun banarekin burutu dira elkarrizketak. Bestalde, kalitate kudeaketaren arloan esperientzia oparoa duten aholkulari eta bestelako adituekin ere informazioa kontrastatu nahi izan da; gure eskerrik beroena, beraz, parte hartu duten pertsona horiei guztiei.

Aipatu elkarrizketatan jasotako gogoetek eta literatura akademikoan aurki daitezkeen gai honen inguruko ikerlan nagusienek ondorio bertsuak azpimarratzen dituztela nabarmendu da. UNE 158001 estandarraren bertsio berriak sektore soziosanitarioko erakunde, eta bereziki adineko pertsonen egoitza askorentzat lehendik ere ezagunak 
zituzten adierazle, programa eta hobekuntzarako proposamen berri jakin batzuk baino ez ditu jasotzen. Hala ere, kudeaketa profesionalizatu eta kudeaketa beste jarduera esparru batzuetan izan ohi denarekin parekatzen jarraitzeko baliagarritzat jotzen dute. Finean, UNE 158001 estandarra bezalako eredu espezifikoaren arabera lan egitea ez dute erakargarri ikusten, eta are gutxiago ISO 9001 estandarrarekin -kalitate kudeaketarako nazioarteko erreferentzia nagusienarekin- lehendik ere lanean dihardutela jakinik.

Azken batean, adineko pertsonen egoitzetan kudeaketa sistemen garapenak antolaketa arloko hobekuntza, kudeaketaren izaera profesionala eta jardueren sistematizazioa ekarri ditu. Baina Leturiak (2012) azpimarratzen duen gisara, "kalitatearen kudeaketarako sistema, ziurtagiri eta hauekin loturiko bestelako aitortzek ez dute - bere horretaneskainitako arretaren kalitatea bermatzen. Areago, antolaketa arloko eta eskainitako zerbitzuari dagokion kalitateak pertsona erabiltzailearen bizi kalitatean eragin zuzena izan behar dute”. Sarri askotan, adineko pertsonei arreta eta zaintza zerbitzuak eskaintzen dizkieten zentro batzuek bigarren mailan jarri izan dituzte oinarrizkoak behar luketen helburuak. KKS-en garrantzia albo batera utzi gabe, mendekotasun egoeran dauden pertsona horiekin lan egiten duten antolaketek euren funtsezko helburuak betetzeko euskarri eta bideratzaile bezala erabili beharko lituzkete sistema horiek (Leturia, 2012).

Adineko pertsonen egoitza, eguneko edo gaueko zentro, etxez etxeko zerbitzu eta telelaguntza zerbitzuan gertatzen ari diren aldaketak sektore honetako antolaketen kudeaketa paradigma berriaren isla dira, - hein batean- politika publikoek eta gizarte talde desberdinek eragindako aldaketen isla (Rodríguez, 2011). Osasunaren Mundu Erakundeak (OME) 2015. urtean argitaratutako Zahartzaroa eta Osasunari buruzko mundu mailako txostenean aipatzen duenez, adineko pertsonen bizimoduarekin erlazionatutako aspektu guztietan arreta integratua barneratzeko beharra berebizikoa da; alegia, adineko pertsonen egoitzetan eskaintzen diren prozesuen antolakuntzaren kalitatea sistematizatu, formalizatu eta neurtzeko balio duten KKS-en eta adineko pertsonei eskaini beharreko arretaren kalitatea - sektorean benetako gakoauztartuz. OME-k dioenez, adineko pertsonak eskuartzearen erdigunean jartzea litzateke erronka: autonomia osoa duten subjektu gisa, eta zer-nolako bizimodua nahi duten erabakitzeko gaitasunarekin (OME, 2015).

\section{Eskertzak}

Artikulu hau Eusko Jaurlaritzak finantzaturiko IT107316 - GIC 15/176 ikerketa taldeen baitan garatu da. 
AENOR (2007): Norma UNE 158101 de Servicios para la Promoción de la Autonomía Personal. Gestión de Centros Residenciales y Centros Residenciales con Centro de Día o Centro de Noche Integrado., Requisitos, Madril, AENOR Ediciones.

- (2000): Norma UNE 158001 de Gestión de Servicios en las Residencias de Mayores, Madril, AENOR Ediciones.

ÁLVAREZ, M. (2007): "Calidad asistencial en centros gerontológicos”, Revista Española de Geriatría y Gerontología, 1. bol., 42. zb., 75-85 or.

ANTTILA, J.; eta JUSSILA, K. (2017): “ISO 9001:2015, a questionable reform. What should the implementing organisations understand and do"?, Total Quality Management \& Business Excellence, 9. bol., 28. zb., 1-16 or.

BECK, N.; eta WALGENBACH, P. (2005): "Technical efficiency of adaptation to institutional expectations? The adoption of ISO 9000 standards in the Geran mechanical engineering industry, Organization Studies, 26. zb., 841-866 or.

BOIRAL, O.; eta GENDRON, Y. (2011): "Sustainable development and certification practices: lessons learned and prospects", Business Strategy and the Environment, 20. zb., 331-347 or.

HERAS, I. (2008): “Calidad sustantiva versus calidad superficial”, Gizarte.doc, 26. zb., 7. or.
- (2004): Enpresaren ekonomia eta zuzendaritza. Teoria eta praktika, Bilbo, Udako Euskal Unibertsitatea.

HERAS-SAIZARBITORIA, I.; eta BOIRAL, O. (2015): "Symbolic adoption of ISO 9000 in small and mediumsized enterprises: The role of internal contingencies", International Small Business Journal, 33. bol., 3. zb., 299-320 or.
- (2013): "ISO 9001 and ISO 14001: Towards a research agenda on management system standards", International Journal of Management Review, 1. bol., 15. zb., 47-65 or.

HERAS-SAIZARBITORIA, I.; BOIRAL, O.; eta ALLUR, E. (2018): "Three decades of dissemination of ISO 9001 and two of ISO 14001: looking back and ahead", in HERAS-SAIZARBITORIA, I. (ed.), ISO 9001, ISO 14001 and New Management Standards. Measuring Operations Performance, Cham, Springer.

HERAS-SAIZARBITORIA, I.; CILLERUELO, E.; eta IRADI, J. (2006): “La normalización y certificación de sistemas de gestión en las residencias de mayores", Zerbitzuan, 40. zb., 31-43 or.

IRADI, J. (2006): Análisis de la integración de las normativas y los modelos genéricos de gestión de la calidad con los modelos de evaluación de la calidad asistencial en el sector de las residencias para personas mayores en la CAPV, [doktoretza tesia], Universidad del País VascoEuskal Herriko Unibertsitatea.

KAHN, J. (1980): Gestión de la calidad en los centros sanitarios, Bartzelona, SG Editores.

LETURIA, M. (2012): Los sistemas de calidad y herramientas de evaluación de los servicios residenciales y su relación con el modelo de atención, Fundación Caser para la Dependencia.

MEDINA, M.E.; eta MEDINA, E. (2011): "La calidad en las leyes de servicios sociales autonómicas" [Adineko Pertsonen Erakundeen Albazeteko 10. Kongresuan aurkeztutako ikerketa].

POWER, M. (2003): "Auditing and the production of legitimacy", Accounting, Organizations and Society, 28. zb., 379-394 or.

RODRÍGUEZ, C.; GÓMEZ, J.; eta BOHÓRQUEZ, A. (2016): “La familia de normas UNE 158001 se actualiza”, 
AENOR: Revista de la Normalización y la Evaluación de la Conformidad, 132. zb., 34-39 or.

SACANELL, E. (1994): "El concepto de calidad en la gestión de los servicios sociales", Zerbitzuan, 26. zb., 63-87 or.

SIIS DOKUMENTAZIO ETA IKERKETA ZENTROA (2001):

Garantía de Calidad-Kalitatea Zainduz: manual de aplicación en residencias para personas mayores, Donostia, SIIS Dokumentazio eta Ikerketa Zentroa.

VILLEGAS, M. eta ROSA, I.M. (2003) “La calidad asistencial: concepto y medida”, Dirección y Organización, 29. zb., 50-58 or. 